\title{
Can a High-Energy Diet Affect the Physical Fitness of Elite Athletes?
}

\author{
Yeldana Yerzhanova ${ }^{1}$, Galya Madiyeva ${ }^{2}$, Zhanna Sabyrbek ${ }^{3}$, Ermek Dilmakhambetov ${ }^{4}$, \\ Kazys Milasius ${ }^{5}$
}

\begin{abstract}
Al-Farabi Kazakh National University, 71 Al-Farabi av., KZ-050040 Almaty, Kazakhstan, eldana_777@mail.ru Al-Farabi Kazakh National University, 71 Al-Farabi av., KZ-050040 Almaty, Kazakhstan, Galiya.Madiyeva@kaznu.kz Al-Farabi Kazakh National University, 71 Al-Farabi av., KZ-050040 Almaty, Kazakhstan, zhanna.sabyrbek@kaznu.kz Al-Farabi Kazakh National University, 71 Al-Farabi av., KZ-050040 Almaty, Kazakhstan, Ermek. Dilmakhanbetov@kaznu.kz

5 Vytautas Magnus University, Education Academy, T. Ševčenkos g. 31, LT-03113 Vilnius, Lithuania, kazys.milasius@vdu.lt
\end{abstract}

\begin{abstract}
The aim of the study was to investigate the effect of high energy diets, which were elaborated by the study authors, on the change of physical fitness of athletes of various sports. 90 athletes aged 17-30 years participated in the research. They were divided into three groups of 30 each. Our research has shown that prepared high-energy diets, used during 3 months in the preparatory period, per week-long training microcycles, had a greater positive effect on changes in the fitness of elite athletes of various sports compared to changes in the fitness of lower-performance athletes.
\end{abstract}

Keywords: athletes, training, rational nutrition, physical fitness, energy intake.

\section{Introduction}

Physical fitness is an athlete's condition that allows him to achieve certain results in a competition. It is acquired through physical, technical, tactical, mental training. It is the athlete's ability to reveal all his / her powers and abilities during the competition: physical abilities, mental stability, determination to fight persistently, practical fighting skills, using the available knowledge and experience (Skernevičius et al., 2011). The result of systematic and rational sports training is a complex expression of the body, health, 
morphological condition, as well as physical and technical fitness, which allows to achieve sports results. Physical fitness mainly depends on physical activity, rest, nutrition, as well as ability to avoid injuries. It is an integral part of holistic personality development, where not only the physical abilities but also the spiritual powers of the athlete are developed (Kenney et al., 2015). Recently, physical activity and sport are gaining more and more importance in modern society and are becoming a significant factor in human activities. The proper connection between physical, mental and spiritual education is becoming an increasingly important educational problem.

Physical activity is a genetically determined part of every person's life (Johnson et al., 2007). Proper education of a young person requires that the social and biological needs of physical activity be met (Bouchard et al., 2007; Landers \& Arents, 2007; Paterson et al., 2007). Physical activity is closely related to mental activity, supports other vital functions of the human body (Coakley \& Dunning, 2000). R. Malinauskas (2003) states that the most important motive for promoting physical activity and achieving maximum sports results is the desire to be healthy, strong, overcome difficulties, become a champion or a record holder. High volume and intensity loads require high tension in the body's functional systems, so it is especially important to properly organize the recovery process. This can be done applying the following measures:

- optimizing the planning of the training process;

- increasing the use of recovery measures, including a special focus on nutritional quality.

In the modern sports system, the second option of measures has recently become more acceptable (Vorobyeva et al., 2011; Jeukendrup, 2017). Many authors analysing the change in athletes' physical abilities suggest that the relationship between the quality of an athlete's health nutrition and his or her athletic excellence is very close, as a rational diet is the basis for good functioning of all body organs and systems (Rozenblium, 2006; Vorobyeva et al.., 2011; Stellingwerff et al., 2011; Burke et al., 2019). If the diet of athletes meets the physiological needs of the body, then it will help maintain health, increase work capacity, and promote recovery after exercising (Jeukendrup \& Gleeson, 2010; Turner, 2018). It is worth noting the opinion of English scientists Maughan and Shirrefs (2011) that rational knowledge of nutrition, correct eating habits are inseparable from modern training methodology of athletes.

According to the World Health Organization (WHO), among the determinants of human health and physical fitness, $40-60 \%$ is lifestyle, which contains $25-30 \%$ of a rational diet. Therefore, by meeting the physiological needs of the body, following a rational diet, athletes can adapt more quickly to fusion loads, recover faster after them (Tutelyan et al., 2011; Baranauskas et al., 2019).

Due to the lack of time, exercise-induced stress in the body, the diet of high-skilled athletes does not always meet the recommendations of a rational diet (Kouloutbani et al., 
2012). Another factor hindering proper nutrition is the lack of knowledge about nutrition (Dolan et al., 2011; Baranauskas et al., 2019).

Sports nutritionists often face the specific needs of athletes in various sports (Mujika $\&$ Burke, 2010). There are many sports where athletes need to strictly control their body weight. The ratio between energy received and energy utilized is important in maintaining the required body weight (Wierman, 2007). Therefore, when creating a diet for athletes, it is necessary to take into account the nature of physical activity, its volume and intensity, training and competition calendar. An athlete's energy needs depend on the training period, climate, and geographic location, also on the athlete's physical, and psychological condition (Stellingwerff et al., 2007). Before the start or when in competition, energy consumption during the same physical activity as during training increases by $25-30 \%$. It has been established that the energy and plastic needs of the body are best met by the ratio of the main nutrients - proteins, fats, carbohydrates 1: 1.2: 4.0. According to the contribution of these nutrients to energy production, proteins account for $16 \%$, fats for $20 \%$, and carbohydrates for $64 \%$ of the energy value. For endurance athletes, energy from fat can be increased by up to $25 \%$ and from carbohydrates by up to $70 \%$ (Jeukendrup \& Gleeson, 2010).

Although the amount of scientific information on the nutrition of athletes is quite abundant, data comparing the effects of nutrition on the physical fitness of athletes in different sports are not yet sufficient. Therefore, we raised a problematic question: how the nutritional factor affects the change in athletes' physical fitness indicators.

In Kazakhstan, the issues of nutrition of elite athletes are still insufficiently researched. It is not fully understood what influence the recipes of rational nutrition have on the physical fitness of athletes and the dynamics of their sports results. Our previous research on the nutrition of Kazakh athletes in various sports has shown that the value of their eating habits and daily regime varies greatly (Yerzhanova et al., 2018; 2019).

The aim of this study to determine whether a high-energy diet can increase the physical fitness of elite athletes, and to compare the data obtained with those of lower-performance athletes who eat usual way.

\section{Methods}

The studies, which aimed to evaluate the effect of our high-energy daily diet on the physical fitness of athletes, involved 90 subjects aged 17-30 years. They were divided into 3 groups of 30 participants each. Subjects in each group were further divided into 2 subgroups of 15 participants each. The first subgroup of each group, consisting of elite athletes, was experimental (E) and the second was control (C). The first subgroup of the first group consisted of 15 volleyball players of the city team participating in the volleyball championship of the country. Their age was 19-22 years, height $-188 \pm 8.38 \mathrm{~cm}$, 
body weight $78.11 \pm 7.68 \mathrm{~kg}$, sports experience on average 7 years. The second subgroup consisted of 15 university team players participating in the student competition. The age of the student team members was $18-20$ years, height $186.2 \pm 6.3 \mathrm{~cm}$, body weight $76.8 \pm 5.7 \mathrm{~kg}$, sports experience -5 years.

The first subgroup of the second group consisted of 15 judo wrestlers, members of the national team, their age was $20-28$ years, height $174.3 \pm 8.3 \mathrm{~cm}$, body weight $78.0 \pm 18.9 \mathrm{~kg}$, average sports experience -8 years, and the second subgroup consisted of university students training at a judo wrestling club. Their age was $18-25$ years, height $171.9 \pm 6.0 \mathrm{~cm}$, body weight $74.9 \pm 18.5 \mathrm{~kg}$, sports experience on average 5 years.

The third group consisted of endurance triathlon athletes, the first subgroup of this group consisted of 15 members of the national team, their age was 18-31 years, height $180.0 \pm 7.2 \mathrm{~cm}$, body weight $-66.5 \pm 7.1 \mathrm{~kg}$, sports experience on average 8.2 years, and the second - triathlon amateurs, university students, their age being 17-24 years, height $178.6 \pm 4.8 \mathrm{~cm}$, body weight $-66.9 \pm 6.8 \mathrm{~kg}$, with average 5 years of sports experience.

The athletes of the experimental subgroups consumed the food rations of our composition for 3 months. The participants in the control subgroups ate normally, at their own discretion.

Athletes trained according to training plans prepared by their sports coaches, which specified the structure and content of the exercise in the individual microcycles of the preparatory period. The physical fitness indicators of the studied athletes were evaluated before and after the experiment by three sports-specific fitness tests.

To assess the physical fitness of the volleyball players, a shuttle run $3 \times 10 \mathrm{~m}$, standing long jump, and a jump with both feet on a $50 \mathrm{~cm}$ high platform in $30 \mathrm{sec}$. The physical fitness of judo wrestlers was assessed by the number of pull-ups, sit-and-lie in $1 \mathrm{~min}$, and the number of push-ups from the floor.

The physical fitness of the triathlon athletes was assessed by the results of $1 \mathrm{~km}$ swimming, $20 \mathrm{~km}$ cycling, and $10 \mathrm{~km}$ running competitions.

The actual composition of the food diet was recorded by means of a questionnaire (Steptoe et al., 1995). The questionnaire included questions about the subjects' sociodemographic data, physical development, level of physical activity per week (amount and duration of training), and diet. In response to the questionnaire, the Atlas of Food and Dishes of Kazakhstan (Sharmanov et al., 2008) was used, which presents the weight of food and dishes made from them in grams. Using this method, the respondents recorded the amount of food and fluids consumed 24 hours a day for a period of 3 days. The value of the daily food ration of the subjects was assessed using the norms of the composition and energy value of the daily food ration, which are typical for athletes of each sport, compiled by A. Pšendinas (2003). The first study found that the energy value of the daily diet of athletes in basically all sports was in line with the recommended rational dietary norms. The average nutritional value of a party's food ration for elite volleyball players was increased based on athletes 'physical development data, the specifics of the sport, 
and the initial energy value of the food ration. It was increased by $16 \%$, protein in the diet by $9 \%$, fat by $12.5 \%$ and carbohydrates by $24 \%$. The energy value of the daily diet of the experimental judo wrestling subgroup was increased by $6.4 \%$, the protein content was reduced by $7.6 \%$, the fat content was reduced by $25.4 \%$, and the carbohydrate content was increased by $36 \%$. The value of the daily diet of the experimental subgroup of triathletes was increased by $12 \%$, protein content by $29 \%$, fat content by $20.3 \%$, and carbohydrate content by $5.2 \%$. The composition and energy value of the diet of the experimental and control subgroups of athletes was calculated using food chemical composition tables and a standard computer program adapted for such studies. The research was approved by the Ethics Committee of al-Farabi University in Kazakhstan. Confidentiality of the study results was ensured.

The results of the research were calculated by the methods of mathematical statistics. The arithmetic mean, standard deviation, and error of the arithmetic mean of the data were calculated, and the Student's t criterion was used to evaluate the reliability of their difference.

\section{Results}

The energy value of our elite volleyball team members' diet was increased to $4.685 \mathrm{kcal}$, while the energy value of the student team members' diets reached $4.033 \mathrm{kcal}$. The protein content in the diet of the experimental subgroup was increased from 162.2 to $193 \mathrm{~g}$, the fat content - from 159 to $174 \mathrm{~g}$, and the carbohydrate content - from 472 to $586 \mathrm{~g}$. The total volume of physical activity of the elite volleyball team was 17 hours per week, and the athletes trained for an average of 2 hours and 50 minutes on each training day. The student team load was 10 hours per week. The average duration of one workout was 2 hours.

Studies have shown that when the members of the experimental subgroup consumed a high-energy diet, the physical fitness of the volleyball players increased more than in the control subgroup over an experimental 3-month period. The shuttle run result improved from $8.65 \pm 0.09$ to $8.25 \pm 0.07 \mathrm{sec}$. ( $\mathrm{p}>0.05)$. The result of the standing long jump also had a tendency to improve. In the experimental subgroup of volleyball players, this indicator increased from $233.9 \pm 1.8$ to $239.8 \pm 1.9 \mathrm{~cm}(\mathrm{p}>0.05)$, while the members of the control subgroup changed this indicator slightly. The number of jumps on $50 \mathrm{~cm}$ platform increased on average from $22.8 \pm 0.4$ to $27.9 \pm 0.6$ jumps $(\mathrm{p}<0.05)$ during $30 \mathrm{sec}$ (Table 1). Comparing the results of the three experiments of the experimental and control subgroup of volleyball players, it can be stated that the change in the results of the shuttle run and long jump was statistically unreliable ( $p>0.05)$, and the difference in the special volleyball test was statistically significant $(\mathrm{p}<0.05)$. 
Table 1

Changes in Vollyeball Players' Physical Fitness Indicators During the Experimental Period

\begin{tabular}{|c|c|c|c|c|c|c|}
\hline Tests & Groups & Stages & & $\mathbf{S}$ & Sx & $\mathbf{p}$ \\
\hline \multirow{4}{*}{ Shuttle run 3 x10 m (sec) } & \multirow{2}{*}{$\mathrm{E}$} & Before & 8.65 & .33 & .09 & \\
\hline & & After & 8.25 & .27 & .07 & $>0.05$ \\
\hline & \multirow{2}{*}{$\mathrm{C}$} & Before & 8.70 & .36 & .09 & \\
\hline & & After & 8.60 & .34 & .09 & $>0.05$ \\
\hline \multirow{4}{*}{ Standing long jump (cm) } & \multirow{2}{*}{$\mathrm{E}$} & Before & 233.9 & 7.1 & 1.8 & \\
\hline & & After & 239.8 & 7.6 & 1.9 & $>0.05$ \\
\hline & \multirow{2}{*}{$\mathrm{C}$} & Before & 232.7 & 6.0 & 1.6 & \\
\hline & & After & 233.9 & 5.7 & 1.5 & $>0.05$ \\
\hline \multirow{4}{*}{$\begin{array}{l}\text { Jumping on a platform in } \\
30 \mathrm{sec}\end{array}$} & \multirow{2}{*}{$\mathrm{E}$} & Before & 22.8 & 1.8 & .4 & \\
\hline & & After & 27.9 & 2.3 & .6 & $<0.05$ \\
\hline & \multirow{2}{*}{$\mathrm{C}$} & Before & 22.4 & 1.2 & .3 & \\
\hline & & After & 23.3 & 1.4 & .4 & $>0.05$ \\
\hline
\end{tabular}

The energy value of elite judo wrestling athletes' diet of our composition was increased by an average of 6110 to $6499 \mathrm{kcal}$ compared to the lower-level wrestlers' diet, but the protein content was reduced from 281.5 to $260 \mathrm{~g}$ and the fat content was reduced from 372.9 to 278 g.; carbohydrates - increased from 542.8 to $739 \mathrm{~g}$. The total physical activity volume of elite judo wrestlers was 17 hours 15 minutes per week, and the daily training of the wrestlers lasted an average of 2 hours 52 minutes. University wrestlers' training lasted on average of 1 hour 48 minutes.

Due to the high-energy food ration we prepared, the physical fitness of the judo wrestlers of the experimental subgroup tended to increase. The number of pull-ups increased on average from $38.5 \pm 1.8$ to $42.1 \pm 1.8$ times ( $\mathrm{p}>0.05$ ), but this increase was not statistically significant. The result of this exercise for the members of the control subgroup remained almost unchanged. The result of lifting the torso from a lying position to a sitting position (sit-and-lie test) increased on average from $71.0 \pm 1.4$ to $75.4 \pm 1.4$ times in $1 \mathrm{~min}(\mathrm{p}>0.05)$. The number of push-ups also tended to increase on average from $89.5 \pm 2.5$ to $93.9 \pm 2.5$ ( $\mathrm{p}>0.05$ ) (Table 2). Comparing the change in physical fitness indicators of the experimental and control subgroup of judo wrestlers, we see that the difference in the change in the results of all three tests is statistically unreliable $(p>0.05)$. 
Table 2

Changes in the Physical Fitness Indicators of Judo Wrestlers During the Experimental Period

\begin{tabular}{|c|c|c|c|c|c|c|}
\hline Indicators & Groups & Stages & & $S$ & $S_{\mathbf{x}}$ & $\mathbf{p}$ \\
\hline \multirow{4}{*}{ Pull-ups (number) } & \multirow{2}{*}{$\mathrm{E}$} & Before & 38.5 & 7.1 & 1.8 & \\
\hline & & After & 42.1 & 7.1 & 1.8 & $>0.05$ \\
\hline & \multirow{2}{*}{$\mathrm{C}$} & Before & 38.0 & 6.0 & 1.6 & \\
\hline & & After & 38.7 & 6.4 & 1.7 & $>0.05$ \\
\hline \multirow{4}{*}{ Sit-and-lie in $1 \mathrm{~min}$. (number) } & \multirow{2}{*}{$\mathrm{E}$} & Before & 71.0 & 5.3 & 1.4 & \\
\hline & & After & 75.4 & 5.5 & 1.4 & $>0.05$ \\
\hline & \multirow{2}{*}{$\mathrm{C}$} & Before & 69.7 & 4.5 & 1.2 & \\
\hline & & After & 70.7 & 4.4 & 1.1 & $>0.05$ \\
\hline \multirow{4}{*}{ Push-ups (number) } & \multirow{2}{*}{$\mathrm{E}$} & Before & 89.5 & 9.5 & 2.5 & \\
\hline & & After & 93.9 & 9.8 & 2.5 & $>0.05$ \\
\hline & \multirow{2}{*}{$\mathrm{C}$} & Before & 88.5 & 9.5 & 2.5 & \\
\hline & & After & 89.7 & 9.3 & 2.4 & $>0.05$ \\
\hline
\end{tabular}

The energy value of the food ration we compiled for the members of the national team was increased on average from 4967 to $5562 \mathrm{kcal}$ compared to the value of the food ration of the less skilled triathletes. The amount of protein in their diet was increased from 163.6 to $211 \mathrm{~g}$ on average, from 184.5 to $222 \mathrm{~g}$ of fat, and from 646.2 to $680 \mathrm{~g}$ of carbohydrates. The total volume of physical activity of the triathlon athletes of our national team during the weekly training microcycle averaged 20 hours, and every day - 3 hours 10 minutes. Members of the control subgroup trained for an average of 10 hours per week and their training lasted an average of 2 hours.

Studies of the physical fitness of triathlon athletes showed that the $1 \mathrm{~km}$ distance of swimming results of elite athletes improved on average from $742.3 \pm 10.4$ to $714.3 \pm 9.9 \mathrm{~s}$ (from 12.37 to $12.09 \mathrm{~min}$ ) ( $\mathrm{p}>0,05)$, but this increase was not statistically reliable (Table 3 ). The result of cycling the $20 \mathrm{~km}$ distance increased statistically reliably - from $2158.3 \pm 43.4$ to $2098.5 \pm 41.9 \mathrm{~s}$ (from 36.32 to $35.06 \mathrm{~min})(\mathrm{p}<0.05)$, and the distance of $10 \mathrm{~km}$ running result improved from $1935.3 \pm 15.0$ to $1863.7 \pm 13.9 \mathrm{~s}$ (from 32.25 to $31.06 \mathrm{~min})(\mathrm{p}<0.05)$. In the control subgroup participants, these indicators changed insignificantly. The change in swimming results between the experimental and control subgroup of triathletes was statistically unreliable ( $p>0.05)$, but the difference between the change in the $20 \mathrm{~km}$ cycling distance and the $10 \mathrm{~km}$ running result change was statistically significant $(\mathrm{p}<0.05)$. 
Table 3

Changes in Triathlon Athletes' Physical Fitness Indicators During the Experimental Period

\begin{tabular}{|c|c|c|c|c|c|c|}
\hline Indicators & Groups & Stages & & $S$ & $S_{\mathbf{x}}$ & $\mathbf{p}$ \\
\hline \multirow{4}{*}{ Swimming, 1 km (sec) } & \multirow{2}{*}{$\mathrm{E}$} & Before & 742.3 & 40.3 & 10.4 & \\
\hline & & After & 714.3 & 38.5 & 9.9 & $>0.05$ \\
\hline & \multirow{2}{*}{$\mathrm{C}$} & Before & 748.93 & 31.6 & 8.2 & \\
\hline & & After & 744.8 & 23.1 & 6.0 & $>0.05$ \\
\hline \multirow{4}{*}{ Bycycle ride $20 \mathrm{~km}$ (sec) } & \multirow{2}{*}{$\mathrm{E}$} & Before & 2158.3 & 168.1 & 43.4 & \\
\hline & & After & 2098.5 & 162.4 & 41.9 & $<0.05$ \\
\hline & \multirow{2}{*}{$\mathrm{C}$} & Before & 2158.8 & 168.0 & 43.4 & \\
\hline & & After & 2149.2 & 166.3 & 42.9 & $>0.05$ \\
\hline \multirow{4}{*}{ Running 10 km (sec) } & \multirow{2}{*}{$\mathrm{E}$} & Before & 1935.3 & 58.0 & 15.0 & \\
\hline & & After & 1863.7 & 53.8 & 13.9 & $<0.05$ \\
\hline & \multirow{2}{*}{ C } & Before & 1939.9 & 61.2 & 15.8 & \\
\hline & & After & 1927.1 & 62.1 & 16.0 & $>0.05$ \\
\hline
\end{tabular}

\section{Discussion}

The results of the study show that in accordance with the principles of rational nutrition, a balance must be maintained between the principle of energy received and energy consumed. Many authors state that proper nutrition is the most important factor in determining an athlete's body's adaptation to exercise (Dolan et al., 2011; Tutelyan et al., 2011; Nowacka et al., 2016). Rational and nutritional rules also provide proper nutrition, its mode, which must strictly match the structure and content of endurance training (Jeukendrup, 2011). As stated by Tutelyan et al. (2010), Dundorf (2010), Kouloutbani et al. (2012), Boguszewski et al. (2013), a diet that meets these requirements promotes positive changes in the physical and functional abilities of athletes. Spronk et al. (2015), studying the dependence of the nutritional quality of Australian elite athletes on the relationship between knowledge of rational nutrition and sports performance, argue that there is no statistically significant reliable difference between individual sports and gaming athletes' knowledge of nutritional quality progress of the results.

When training volleyball players, the main focus is on building their speed and strength. These abilities determine the result of a jump up by building an obstacle for the opponent, the speed of movement and the accuracy of the action with the ball (Mujika 
\& Burke, 2010). Therefore, a well-balanced diet of volleyball players must meet energy needs to enable these abilities to be employed (Gabbett \& Georgieff, 2007). The game of volleyball requires quite a lot of energy, and the skills of speed, strength and technical readiness must be well developed (Anderson et al., 2007). In volleyball, energy produces more in anaerobic lactate energy production way, which accounts for about $90 \%$ of all energy produced (Zapolska et al., 2014). As reported by Mielgo-Ayuso et al., (2013), a diet rich in carbohydrates increases energy stores and allows for the accumulation of more glycogen in the muscles, which in turn increases the sudden muscle strength inherent and important for volleyball players. Comparing the results of our study with the energy value and carbohydrate intake of young volleyball players in different countries presented by F. Holway and L. Spriet (2011), we see that the daily energy value of Kazakh volleyball players is higher and carbohydrate is consumed more. It is also important for players in this sport to get the right amount of protein to build up the necessary stores of creatine phosphate and rapid tissue regeneration (Papandreu et al., 2006).

Judo wrestling is one of the most dynamic types of sport wrestling, which combines strength, speed of movement and technique (Bellinger, 1997). Energy needs vary greatly during competitions. The predominant type of energy production is anaerobic, but the aerobic energy production system also plays a significant role (Teshima et al., 2002; Clarys et al., 2010). Our research has shown that proteins in the diet of judo wrestlers exceeds the recommended daily allowance $(1.2-1.8 \mathrm{~g} / \mathrm{kg})$ and reaches $3.3 \mathrm{~kg}$, but Laskowski and Antosiewicz (2003) state that the representatives of this sport, which build strength and muscle power, need to increase the amount of protein in their diet. However, Mekic et al. (2018) note that a specific physical training program is of paramount importance in developing the skills of elite judo wrestlers. There are weight categories in the judo sport, so Boisseu et al. (2005) believe that nutrition is one of the most important factors in regulating body weight. We have not investigated this issue in our work, but we fully agree with the opinion of these authors.

The success of endurance athletes depends on the ability of the aerobic energy production system to supply energy to the working muscles (Jeukendrup, 2011; Kolby et al., 2020). The analysis of literature sources shows that in the preparation of triathletes for the most important competitions, in order to avoid negative consequences, the study of their actual diet is important (Tiller et al., 2019). Only by evaluating the nutrition of athletes, it will be possible to properly organize the training process and successfully participate in competitions (Papandreu et al., 2007; Dolan et al., 2011). The specifics of the training of triathlon athletes are characterized by the fact that the content of this sport consists of 3 sports, the exercises last a long time, 3-4 hours. This places special demands on the body's energy supply, and the a mount of essential energy in the diet must be well balanced (Finch, 2004; Jeukendrup et al., 2005; Bentley, 2008). E. Applegate (1991) indicates that the daily energy consumption of elite triathletes can reach up to $6000 \mathrm{kcal}$. The energy value of the diet of our studies elite triathletes was $5562 \mathrm{kcal}$. Their exercise volume was 
20 hours per week and an average of 3 hours 10 minutes each day. According to Dolan et al. (2011), balancing the amount of exercise, diet, and health status of an athlete is particularly important when performing an exercise of this or even greater training load. These authors also point out that triathlon competitions and training require additional nutrition. If the exercise and competition last more than three hours, $99 \%$ of the 400 triathletes surveyed consumed extra food and energy drinks. Easy-to-digest, carbohydrate-rich foods, multivitamins and minerals, amino acids, caffeine, and glucose are consumed. According to N. Tiller et al., (2019), elite triathletes weighing at least $80 \mathrm{~kg}$ consume 5300-5500 kcal in three hours of physical activity.

\section{Conclusions}

Our research has shown that prepared high-energy diets, used during week-long training microcycles, had a greater positive effect on changes in the fitness of elite athletes of various sports compared to changes in the fitness of lower-performance athletes. Greater progress in results was found of endurance physical tests which are typical to triathlon sport. However, changes in physical fitness test results for most experimental subgroups in all 3 sports were not statistically significant. Based on the results of this study, it can be concluded that a high-energy diet is not the most important factor determining the physical fitness of athletes.

\section{References}

Anderson, L., Naughton, R., Close, G., Michele, R., Morgans, R., Drust, B., \& Morton, J. (2017). Daily distribution of macronutrient intakes of professional soccer players from the english premier league. International Journal of Sport Nutrition and Exercise Metabolism, 27(6), 491-498. doi: https://doi.org/10.1123/ijsnem.2016-0265

Applegate, E. A. (1991). Nutritional considerations for ultra-endurance performance. International Journal of Sport Nutrition, 1, 118-126.

Baranauskas, M., Stukas, R., Jablonskienė, V., Abaravičius, J., Paškevičienè, D., Tubelis, L., \& Švedas, E. (2019). Promoting and limiting factors of nutritional habits and dietary supplement use among high performance athletes in Lithuania. Sport Science, 1(95), 39-45. https://doi. org/10.15823/sm.2019.95.5

Bellenger, S. (1997). Wrestling with wrestling. Training Conditioning, 7, 50-55.

Bentley, D., Cox, G., Green, D., \& Laursen, P. (2008). Maximising performance in triathlon: Applied physiological and nutrition aspects of elite and non-elite competitions. Journal of Science and Medicine in Sport, 11, 407-416. 
Boguszewski, D., Adamczyk, J., Buda, M., \& Bialoszewski, D. (2013). The estimation of healthrelated behaviours of male judokas. Journal of Combat Sports and Martial Arts, 4(2), 179-184, https://doi.org/10.5604/20815735.1090675.

Bouchard, C., Blair, S., Haskell, W. (2007). Physical activity and health. Champaign, IL.: Human Kinetics Publ.

Burke, L., Jeukendrup, A., Jones, A., \& Mooses, M. (2019). Contemporary nutrition strategies to optimize performance in distance runners and race walkers. International Journal of Sport Nutrition \& Exercise Metabolism, 29(2), 117-129.

Clarys, P., Ramon, K., Hagman, F., Deriemaeker, P., \& Zinzen, E. (2010). Influence of weight reduction on physical performance capacity in judokas. Journal of Combat Sports and Martial Arts, 1(2), 71-76.

Coackley, J., \& Dunning, E. (2000). Handbook of Sports Studies. London.: Sage Publications.

Dolan, S. H., Houston, M., \& Martin, S. (2011). Survey results of the training, nutrition, and mental preparation of triathletes: Practical implications of findings. Journal of Sports Sciences, 29(10), 1019-1028. http://dx.doi.org/10.1080/02640414.2011.574718.

Dunford, M. (2010). Fundamentals of sport and exercise nutrition. Champaign, IL.: Human Kinetics Publ.

Finch, M. (2004). Nutrition in triathlon / Ed. M Finch, Triathlon training. Champaign, IL.: Human Kinetics, 102-115.

Gabbett, T., \& Georgieff, B. (2007). Physiological and anthropometric characteristics of Australian junior national, state, and novice volleyball players. Journal of Strength and Conditioning Research, 21(3), 902-908.

Holway, F., \& Spriet, L. (2011). Sport-specific nutrition: practical strategies for team sports. Journal of Sport Science, 29(1), 115-125.

Jeukendrup, A., Jentjens, R., \& Moseley, L. (2005). Nutritional considerations in triathlon. Sports Medicine, 35, 163-181.

Jeukendrup, A., \& Gleeson, M. (2010). Sport nutrition: an introduction to energy production and performance. Human Kinetics.

Jeukendrup, A. (2011). Nutrition for endurance sport: marathon, triathlon and road cycling. Journal of Sport Science, 29(1), 91-99.

Jeukendrup, A. (2017). Training the gut for athletes. Sports Medicine, 47(1), 101-110. doi: 10.1007/ s40279-017-0690-6

Johnson, L., Delva, J., \& Malley, P. (2007). Sports participation and physical education in American secondary schools: current levels and racial, ethnic and socioeconomic disparities. American Journal of Preventive Medicine, 33(4), 195-218.

Kenney, W., Wilmore, J., \& Costill, L. (2015). Physiology of sport and exercise. Champaign, IL.: Human Kinetics.

Kolby, N., Tandrup, L., \& Jeppesen, P. (2020). The effect of ingesting carbohydrate and proteins on athletic performance: a systematic review and meta-analysis of randomized controlled trials. Nutrients, 12(5), 1483. doi: 10.3390/nu12051483 
Kouloutbani, K., Eftsathiou, T., \& Stergioulas, A. (2012). Eating disorders in the world of sport; the experiences of rhythmic gymnasts. Journal of Biology of Exercise, 8(2), 19-31.

Landers, D. M., \& Arent, S. M. (2007). Physical activity and mental health. In G. Tenenbaum \& R. C. Eklund (Eds.), Handbook of sport psychology (pp. 469-491). Hoboken, NJ.: John Wiley \& Sons, Inc.

Malinauskas, R. (2003). Motivation peculiarities in duel sports athletes of high performance and reserve of duel sports, Sport Science, 1, (31), 19-23.

Mekic, A., Kajmovic, H., Kapo, S., Bajramovič, I., \& Čovič, N. (2018). Effects of specific programmed training on physical fitness, physiological and performance responses in elite judokas. Homo Sporticus, 2, 10-23.

Mielgo-Ayuso J., Collado, P. S., Urdampilleta, A., Martínez-Sanz, J. M., \& Seco, J. (2013). Changes induced by diet and nutritional intake in the lipid profile of female professional volleyball players after 11 weeks of training. Journal of the International Society of Sports Nutrition, 10 (1), 55-61.

Mujika, I., \& Burke, L. M. (2010). Nutrition in team sports. Annals of Nutrition and Metabolism, $57,26-35$.

Nowacka, E., Leszczynska, T., Kopec, A., \& Hojka, D. (2016). Nutritional behaviour of polish canoeist athletes. The interest of nutritional education. Science and Sports, 31(4), 79-91. doi: 10.1016/j.scispo.2016.04.002

Papandreou, D., Hassapidou, M., Hourdakis, M., Papakonstantinou, K., Tsitskaris, G., \& Garefis, A. (2006). Dietary intakes status of elite athletes. Aristotle University Medical Journal, 33(1), 119-126.

Papandreou, D., Eystathiadis, P., Bouzoukiu, V., Hassapidou, M., Tsitskaris, G., \& Garefis, A. (2007). Dietary assessment, anthropometric measurements and nutritional status of Greek professional athletes. Nutrition and Food Science, 37(5), 338-344.

Paterson, D., Jones, G., \& Rice, C. (2007). Ageing and physical activity: evidence to develop exercise recommendations for older adults. Canadian Journal of Public Health, 98(2), 69-108.

Skernevičius, J., Milašius, K. Raslanas, A., Dadelienè, R. (2011). Sporto treniruote. Monografija. Vilnius: Vilniaus pedagoginis universitetas.

Spronk, I., Heaney, S., Prvan, T., \& O’Connor, H. (2015). Relationship between general nutrition knowledge and dietary quality in elite athletes. Internationl Journal of Sport Nutrition \& Exercise Metaolism, 25(3), 243-251.

Stellingwerff, T., Boit, M., \& Res, P. (2007). Nutritional strategies to optimize training and racing in middle-distance athletes. Journal of Sport Science, 25(1), 17-28.

Stellingwerff, T., Maughan, R., \& Burke, L. (2011). Nutrition for power sports: middle-distance running, track cycling, rowing, canoeing/kayaking, and swimming. Journal of Sport Science, 29(1), 79-89.

Steptoe A., Pollard T., \& Wardle, J. (1995). Development of a measure of the motives underlying the selection of food: the food choice questionnaire, Appetite, 25(3), 267-284. 
Teschima, K., Imamura, H., Yoshimura, Y., Nishimura, S., Miyamoto, N., Yamauchi, Y., Hori, H., Moriwaki, C., \& Shirota, T. (2002). Nutrient intake of highly competitive male and female collegiate karate players. Journal of Physiological Anthropology and Applied Human Science, 21(4), 205-211.

Tiller, N., Roberts, J., Beasley, L. et al. (2019). International society of sport nutrition position stand: nutritional considerations for single-stage ultra-marathon training and racing. Journal of the International Society of Sports Nutrition, 16(1), 1.

Turner, L. (2018). Healthy eating made easy. Better Nutrition, 80(2), 40-44.

Tutelyan, V., Minkayil, M., Baturin, A., Nikityuk, D., Ordzhonikidze, Z., \& Pozdnyakov A. (2011). On the significance of the individual nutrition for top athletes. Voprosy Pitania [Problems of Nutrition], 80(5), 78-83.

Vorobyeva,V. M., Shatnyuk, L. N.,Vorobyeva, I. S., Mikheeva, G. A., Muravyova, N. N., Zorina, E. E., \& Nikityuk, D. B. (2011). The role of nutritional factors in intensive physical activities of sportsmen. Problems of Nutrition, 80(1), 70-77.

Wierman, T. (2007). Nutrition for swimmers: Eat to win. American Swimming, 25-30.

Yerzhanova, Y., Sabyrbek, Zh., Dilmakhanbetov, E., \& Milasius, K. (2018). Mode and food habits of athletes of Kazakhstan. Pedagogics Psychology Medical-Biological Problems of Physical Training and Sports, 6, 328-334. doi.org/10.15561/18189172.2018.0608

Yerzhanova, Y., Sabyrbek, Zh., Dilmakhanbetov, E., Madiyeva, G., \& Milasius, K. (2019). Evaluation of knowledge and competence of Kazakhstani athletes about nutrition. Sport Mont Journal, 17(2), 9-13. doi: 10.26773/smj.190615

Zapolska, J., Witczak, K., Mańczuk, A., \& Ostrowska, L. (2014). Assessment of nutrition, supplementation and body composition parameters on the example of professional volleyball players Roczniki Państwowego Zakładu Higieny, 65(3), 235-242.

Мохан, Р., Ширрефс, С. (2011). Новые направления в спортивном питании [New directions in sports nutrition]. Спортивна медицина, 1-2, 3-10.

Пшендин, А. И. (2003). Рациональное питание спортсменов [Rational nutrition of athletes]. Санкт-Петербург.

Розенблюм, К. А. (2006). Питание спортсменов. Руководство для профессиональной работы с физически подготовленньми людьми [Nutrition for athletes. A guide for professional work with physically fit people]. Киев: Олимпийская литература.

Тутельян, В., Никитюк, Д., Поздняков, А. (2010). Оптимизация питания спортсменов: реалии и перспективы [Optimisation of nutrition for athletes: realities and prospects]. Вопросы питания, 79(3), 78-82.

Шарманов, Т. Ш., Айджанов, М. М., Берденова, Г. Т., Салханова, А. Б. (2008). Тағам мөлшерінің альбомы [Albums of food products]. Қазақ тағамтану академиясы, Алматы. 


\section{Ar gali padidintos energetinès vertès dieta veikti didelio meistriškumo sportininkų fizini parengtumą?}

Yeldana Yerzhanova $^{1}$, Galya Madiyeva ${ }^{2}$, Zhanna Sabyrbek ${ }^{3}$, Ermek Dilmakhambetov ${ }^{4}$, Kazys Milasius ${ }^{5}$

1 Kazachstano Al-Farabi nacionalinis universitetas, Al-Farabi aleja 71, KZ-050040 Almata, Kazachstanas, eldana_777@mail.ru

2 Kazachstano Al-Farabi nacionalinis universitetas, Al-Farabi aleja 71, KZ-050040 Almata, Kazachstanas, Galiya.Madiyeva@kaznu.kz_

3 Kazachstano Al-Farabi nacionalinis universitetas, Al-Farabi alejja 71, KZ-050040 Almata, Kazachstanas, Zhanna.Sabyrbek@kaznu.kz

4 Kazachstano Al-Farabi nacionalinis universitetas, Al-Farabi aleja 71, KZ-050040 Almata, Kazachstanas, Ermek.Dilmakhanbetov@kaznu.kz

5 Vytauto Didžiojo universitetas, Švietimo akademija, T. Ševčenkos g. 31, 03111 Vilnius, Lietuva, kazys.milasius@vdu.lt

\section{Santrauka}

Tyrimo tikslas - nustatyti, ar gali padidintos energetinès vertès dieta veikti didelio meistriškumo sportininkų fizinị parengtumą, ir gautus duomenis palyginti su mažesnio meistriškumo sportininkų, kurie maitinasi ịprastu būdu, parengtumo duomenimis.

Buvo ištirta trijų ugdančių skirtingus fizinius gebejimus sporto šakų 90 sportininkų, kurių paros maisto raciono energetinė vertẻ buvo didesnè nei mažesnio sportinio meistriškumo sportininkų. Ekspermentinių pogrupių sportininkai mūsų sudarytos sudèties, padidintos energetinès vertès maisto racioną vartojo 3 mėnesius. Sportininkų vartojamų maisto produktų sudèčiai ir jų energetinei vertei įvertinti buvo taikyta Steptoe ir kt. (1995) anketa. Tiriamųjų sportininkų fizinio parengtumo rodikliai buvo įvertinti prieš eksperimentą ir po jo trimis būdingais tai sporto šakai fizinių gebejimų testais.

Mūsų atlikti tyrimai parodè, kad paruošti padidintos energetinès vertès maisto racionai, vartojami savaitės trukmès treniruočių mikrociklų metu, turejjo didesnę teigiamą ịtaką įvairių sporto šakų didelio meistriškumo sportininkų fizinio parengtumo rodiklių kaitai palyginti su mažesnio sportinio meistriškumo sportininkų fizinio parengtumo rodiklių pokyčiais. Didesnis rezultatų progresas buvo nustatytas atliekant ištvermès reikalaujančius fizinius pratimus. Vis dèlto daugumos visų trijų sporto šakų eksperimentinių pogrupių fizinio parengtumo testų rodiklių pokyčiai nebuvo statistiškai patikimi. Atsižvelgiant ị šio tyrimo rezultatus galima daryti išvadą, kad padidintos energetinès vertės racionas yra reikšmingas, tačiau nèra svarbiausias sportininkų fizinị parengtumą sąlygojantis faktorius.

Esminiai žodžiai: sportininkai, rengimas, racionali mityba, fizinis parengtumas, energijos suvartojimas. 